Boston University School of Law

Scholarly Commons at Boston University School of Law

Faculty Scholarship

Spring 2022

\title{
The Electoral Count Mess: The Electoral Count Act of 1887 Is Unconstitutional, and Other Fun Facts (Plus a Few Random Academic Speculations) about Counting Electoral Votes
}

Jack M. Beermann

Boston University School of Law

Gary S. Lawson

Boston University School of Law

Follow this and additional works at: https://scholarship.law.bu.edu/faculty_scholarship

Part of the Election Law Commons, and the President/Executive Department Commons

\section{Recommended Citation}

Jack M. Beermann \& Gary S. Lawson, The Electoral Count Mess: The Electoral Count Act of 1887 Is Unconstitutional, and Other Fun Facts (Plus a Few Random Academic Speculations) about Counting Electoral Votes, in 16 FIU Law Review 297 (2022).

Available at: https://scholarship.law.bu.edu/faculty_scholarship/1085

This Article is brought to you for free and open access by Scholarly Commons at Boston University School of Law. It has been accepted for inclusion in Faculty Scholarship by an authorized administrator of Scholarly Commons at Boston University School of Law. For more information, please contact lawlessa@bu.edu. 


\section{HEINONLINE}

DATE DOWNLOADED: Fri Oct 7 21:02:40 2022

SOURCE: Content Downloaded from HeinOnline

Citations:

Bluebook 21st ed.

Jack Beermann \& Gary Lawson, The Electoral Count Mess: The Electoral Count Act of 1887 Is Unconstitutional, and Other Fun Facts (plus a Few Random Academic Speculations) about Counting Electoral Votes, 16 FIU L. REV. 297 (2022).

ALWD 7th ed.

Jack Beermann \& Gary Lawson, The Electoral Count Mess: The Electoral Count Act of 1887 Is Unconstitutional, and Other Fun Facts (plus a Few Random Academic Speculations) about Counting Electoral Votes, 16 FIU L. Rev. 297 (2022).

APA 7th ed.

Beermann, J., \& Lawson, G. (2022). The electoral count mess: the electoral count act of 1887 is unconstitutional, and other fun facts (plus few random academic speculations) about counting electoral votes. FIU Law Review, 16(2), 297-326.

Chicago 17th ed.

Jack Beermann; Gary Lawson, "The Electoral Count Mess: The Electoral Count Act of 1887 Is Unconstitutional, and Other Fun Facts (plus a Few Random Academic Speculations) about Counting Electoral Votes," FIU Law Review 16, no. 2 (Spring 2022): 297-326

McGill Guide 9th ed.

Jack Beermann \& Gary Lawson, "The Electoral Count Mess: The Electoral Count Act of 1887 Is Unconstitutional, and Other Fun Facts (plus a Few Random Academic Speculations) about Counting Electoral Votes" (2022) 16:2 FIU L Rev 297.

AGLC 4th ed.

Jack Beermann and Gary Lawson, 'The Electoral Count Mess: The Electoral Count Act of 1887 Is Unconstitutional, and Other Fun Facts (plus a Few Random Academic Speculations) about Counting Electoral Votes' (2022) 16(2) FIU Law Review 297

MLA 9th ed.

Beermann, Jack, and Gary Lawson. "The Electoral Count Mess: The Electoral Count Act of 1887 Is Unconstitutional, and Other Fun Facts (plus a Few Random Academic Speculations) about Counting Electoral Votes." FIU Law Review, vol. 16, no. 2, Spring 2022, pp. 297-326. HeinOnline.

OSCOLA 4th ed.

Jack Beermann \& Gary Lawson, 'The Electoral Count Mess: The Electoral Count Act of 1887 Is Unconstitutional, and Other Fun Facts (plus a Few Random Academic Speculations) about Counting Electoral Votes' (2022) 16 FIU L Rev 297

Provided by:

Fineman \& Pappas Law Libraries

-- Your use of this HeinOnline PDF indicates your acceptance of HeinOnline's Terms and Conditions of the license agreement available at 


\title{
The Electoral Count Mess: The Electoral Count ACT OF 1887 Is UNCONSTITUTIONAL, AND OTHER FUN Facts (Plus a Few Random ACademic Speculations) About COUnTING Electoral Votes
}

\author{
Jack Beermann and Gary Lawson*
}

In this essay, and in light of the controversy that arose in the wake of the 2020 presidential election, we explain the constitutional process for counting electoral votes. In short, every four years, the Twelfth Amendment requires the President of the Senate (usually the Vice President of the United States) to open certificates provided by state presidential electors and count the votes contained therein. The Constitution allows no role for Congress in this process, and thus the provisions of the Electoral Count Act purporting to grant Congress the power, by concurrent resolution, to reject a state's electoral votes are unconstitutional. Further, the objections raised to two states' electoral votes on January 6, 2021, were not proper within the terms of the Act, and therefore, even if Congress has the power specified in the Act, congressional action rejecting States' electoral votes would have been contrary to law. While state executive or state judicially-ordered departures from the requirements of state election laws in presidential elections might violate the federal Constitution's requirement that electors be chosen as specified by state legislatures, determining whether this has taken place is much more complicated than simply examining the language of state election statutes. We suggest that making this determination requires a careful examination of state interpretation traditions that we decline to undertake in this brief essay on the constitutional process for counting electoral votes.

I. INTRODUCTION .298

II. THE CONSTITUTIONAL VOTE COUNTING PROCESS ..........................301

A. The Count ...................................................................... 301

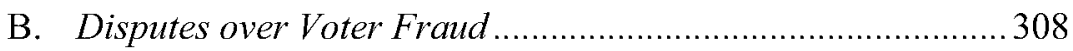

III. THE ELECTORAL COUNT ACT ........................................................3 314

IV. UNCONSTITUTIONAL ELECTIONS.....................................................

\footnotetext{
(C) 2021, all rights reserved. The authors thank John Harrison, Will Baude and the participants at a workshop at University of San Diego School of Law for helpful comments and suggestions. After it was too late to make changes to this article, news emerged that alternate slates of electors were sent to the Vice President and National Archives by some supporters of the losing candidate in the 2020 election. This does not affect our analysis.
} 


\section{INTRODUCTION}

On January 6, 2021, the President of the Senate (Vice-President Mike Pence), presiding over an assemblage of the House and Senate, ${ }^{1}$ received electoral vote certificates from the fifty states and the District of Columbia. At that point, he should have opened the certificates, and, after confirmation that the proper certifications were present, the electoral votes contained therein should have been counted. Nothing more. The entire process should have been over in thirty short minutes.

Instead, the process stretched into the early morning hours of January 7 after nearly nine hours of debate and delay. None of that debate and delay, as far as we can tell, involved the authenticity of the certifications, the identity of the candidates for whom the electoral votes were cast, basic arithmetic, or anything else concerning the reading and counting of votes contained in the certificates.

The causes of the lengthening of the process were two. First, Vice President Pence, applying the Electoral Count Act of 1887, allowed Members of Congress to object to the certificates from Arizona and Pennsylvania, which triggered the Act's requirement that the House and Senate separate and, after a maximum of two hours of debate, vote separately on whether to reject each certificate. ${ }^{2}$ This, despite the facts that a vote to sustain either objection would have been illegal under the Act and that, regardless of compliance with the Act, treating as legally binding a concurrent resolution of Congress rejecting a certificate would be unconstitutional under the Twelfth Amendment. While the Twelfth Amendment is strangely silent about who actually counts the votes in the certificates, the action prescribed in the amendment is counting, not judging. And although it may be appropriate for the Vice President to seek advice from the assembled representatives on whether a document delivered by a State is actually among the "certificates" that must be opened, the decision whether to include a document as a "certificate[]" is committed to the discretion of the Vice President-subject, we believe, to judicial review. Neither Congress nor either House of

1 We use the somewhat awkward phrase "assemblage of the House and Senate" rather than the seemingly more natural phrase "joint session of Congress" because it is far from clear that the meeting of officials prescribed by the Twelfth Amendment is actually a joint session of Congress. See John Harrison, Nobody for President, 16 J. L. \& POL. 699, 703 n.13 (2000) ("The Twelfth Amendment does not call the meeting that it contemplates a joint session. It says that the President of the Senate shall open the certificates in the presence of the Senate and the House of Representatives."); Chris Land \& David Schultz, On the Unenforceability of the Electoral Count Act, 13 RUTGERS J.L. \& PUB. POL'Y 340 (2016).

2 Major brownie points for prescience must go to Ned Foley for predicting, with almost scary accuracy, this course of events. See Edward B. Foley, Preparing for a Disputed Presidential Election: An Exercise in Election Risk Assessment and Management, 51 LoY. U. CHIC. L. REV. 309 (2019). 
Congress is constitutionally authorized to determine what counts as a "certificate."

Second, in the middle of the debate over the first contested certificate, from Arizona, protestors stormed the Capitol building, somehow breaching what, in light of information available to law enforcement well in advance of January 6 , one would have thought would have been tight security. The proceedings halted for nearly six hours while the authorities regained control over the building and determined it was safe for the Vice President, the Members of Congress, and their staffs to return and resume the count. Unfortunately, one protestor was shot and killed by police as she attempted to enter the Capitol building, three more members of the crowd outside the Capitol died after suffering medical emergencies and a Capitol Police officer died shortly after the riot from causes initially thought to have been related to the violence. The saddest fact is that the process should have been over before the shooting occurred, and the protestors should have been informed that there was no legal or constitutional path to having Members of Congress reject any certificate, which might have dampened their ardor for attacking the process. ${ }^{3}$

In this essay we explain, as clearly and simply as possible, the constitutional process for tabulating electoral votes for President and Vice President as mandated by the Twelfth Amendment. We explain that the only constitutional role plausibly attributable to Members of Congress in the tabulation process is the arithmetic counting of votes in certificates opened by the Vice President. It is not at all clear that those Members are even the appropriate vote counters, but they are at least textually possible candidates for that role. Quite possibly they have no role at all. While their physical presence during the vote-counting process is necessary because if no slate receives a majority of the votes represented by the certificates, the Constitution requires the House and Senate to elect a President and Vice President, respectively, they are but mere witnesses to the Vice President's opening of the certificates. ${ }^{4}$

We also explain as a statutory matter that when, as was the case in the procedure arising out of the 2020 presidential election, only one certificate

3 Or perhaps not. Such a notification might have had the opposite effect. If the protestors believed that they were resisting an attempt fraudulently to take over the government, and they were told that there was no legal method to prevent that takeover, it might have prompted even more vigorous action. But to the extent that the protests were grounded in constitutionalist rather than extra-constitutional revolutionary sentiment, accurate information about the Constitution and the constitutional functions of Members of Congress might have been helpful in that particular moment. It is unclear whether any protestor brought a firearm into the Capitol building, leaving some reason to think that good constitutional advice might have been effective rather than incendiary.

4 And their presence may thereby provide some measure of public authentication of the Vice President's actions in opening the certificates. See Harrison, supra note 1, at 705. 
has been provided by a State, the text of the Electoral Count Act specifies that the only legal objection to a certificate that Congress may accept is that it was not provided in the proper form and manner by the appropriate authority of the State according to state law. (This reading of the text is also consistent with the Act's historical context.) In such a situation, the Act provides that each House of Congress debates and votes on the objection, and if both Houses agree, the Vice President may not include the votes represented by that certificate in the tally of the vote for President and Vice President. If enough votes are rejected, this could deprive the apparent winner of the election of a majority of electoral votes, which would throw the presidential election to the House of Representatives for a process in which each State has one vote. In 2021, this might have resulted in the re-election of Donald Trump because a clear majority of States have Republicanmajority delegations in the House.

However, even if enough States had provided statutorily objectionable certificates to deny Joe Biden an electoral majority, we explain that it would be unconstitutional for the assembled House and Senate to reject certificates for any reason, even a reason covered by the Act. Insofar as the Act assigns to Congress even this limited role for consideration of objections, it is unconstitutional. In our view, the Constitution requires that votes submitted by state electors be counted. If there is a genuine dispute over the validity of a certificate, for example if two certificates arrive from a single State or if there are facts suggesting that a certificate delivered to the President of the Senate (usually the Vice President) was not actually sent by a State's electors, the Constitution commits the determination of the certificates to the Vice President, subject to challenge in federal court by a candidate who is denied the Presidency or Vice Presidency due to the Vice President's decision. Any other process would violate the Twelfth Amendment.

We are faced with an additional constitutional puzzle. Article II, section 1 of the Constitution requires States to appoint presidential electors "in such Manner as the Legislature thereof may direct." One of the claims voiced by the objectors to 2020 electoral certificates is that state executive authorities, with agreement in some cases by state courts, altered the process for conducting the election without authority from the legislature. Some of these changes may, by virtue of this language from Article II, constitute federal constitutional violations, so that persons claiming to be electors as a result of those processes may not be "electors" as defined by the Constitution. Determining whether this was so for any State in 2020 would require a careful analysis of state statutes and state traditions concerning the proper roles of executive officials and statutory interpretation in the state courts. This is a

5 U.S. CONST. art. II, $\S 1$, cl. 2. 
complex task that cannot necessarily be carried out simply by a "plain meaning" scrutiny of each State's statutes. After all, the Constitution says that electors must be appointed in the "Manner" directed by the legislature. It does not say what that "Manner" must be or how one must go about ascertaining the legislature's directions regarding that "Manner." Perhaps a public-meaning textualist reading of enacted statutes is any given State's prescribed means for ascertaining those legislative directions, but perhaps it is not; that answer could vary widely from State to State-and indeed could vary widely from time to time within a single State. Happily, we do not need to conduct that analysis to make our fundamental point, which is that the determination of whether the selection of a State's electors complies with Article I is also committed to the sole determination of the Vice President, subject, again to judicial review in federal court. Congress has no constitutional role to play in this or any other dispute over the counting of electors, except, again, to bear witness to the tally and be prepared to perform its constitutionally assigned function if the Vice President's count reveals that no candidate has received a majority of electoral votes.

Many of these arguments were epically made by Vasan Kesavan two decades ago. ${ }^{6}$ We have little to add to his comprehensive account of the problems with the Electoral Count $\mathrm{Act}^{7}$ other than its application to more recent events, the suggestion that the federal courts may have a larger role than Kesavan let on, and the banal observation that the rather blatant unconstitutionality of much of the current statutory electoral scheme remains unacknowledged.

\section{The Constitutional Vote Counting Process}

\section{A. The Count}

The Constitution establishes clear and simple rules for counting electoral vote certificates provided by the States. The Twelfth Amendment requires that state electors (not the governor, secretary of state or other state official) prepare a signed certificate specifying how the State's electoral votes are cast and "transmit [it] sealed" to the President of the Senate. It further provides that "the President of the Senate [usually the Vice President] shall, in the presence of the Senate and House of Representatives, open all the

\footnotetext{
6 See (yes, all 170 pages of it) Vasan Kesavan, Is the Electoral Count Act Unconstitutional?, 80 N.C. L. REV. 1653 (2002).

7 We are not alone in having little to add. See Nathan L. Colvin \& Edward B. Foley, The Twelfth Amendment: A Constitutional Ticking Time Bomb, 64 U. MIAMI L. REV. 475, 478 n.7 (2010) (noting that discussion of the Electoral Count Act's constitutional defects "is brief because Vasan Kesavan has already provided a thorough analysis of the possible constitutional defects of the Electoral Count Act.").
} 
certificates and the votes shall then be counted." Members of Congress are there as witnesses, nothing more. The process of determining who is elected President and Vice President is similarly clear and simple: "the person having the greatest number of votes for President, shall be the President, if such number be a majority of the whole number of Electors appointed." What happens if no candidate wins a majority? Again, clear and simple: "if no person have such majority, then from the persons having the highest numbers not exceeding three on the list of those voted for as President the House of Representatives shall choose immediately, by ballot, the President." A similar process is specified for selection of the Vice President: the Senate rather than the House chooses the winner from the top two vote-getters if no one takes a majority of the electoral votes. And now we know why the votes are counted in the presence of Congress-the House and Senate need to be there in case they are required to carry out their constitutionally prescribed function of choosing a winner if no candidate wins a majority of electoral votes.

There is, of course, a wrinkle, an ambiguity, and a lingering question lurking in this text. The wrinkle is that when the House selects a President, it votes by state delegation with each State having an equal say in the outcome. This wrinkle will take on additional significance when we consider the constitutionality of the Electoral Count Act.

The ambiguity concerns who tabulates the votes once the certificates are opened by the Vice President. The language of the relevant provision is: "The President of the Senate shall, in the presence of the Senate and House of Representatives, open all the certificates and the votes shall then be counted." This provision leaves no doubt about who opens the certificates; that job belongs to the President of the Senate. The provision does not say, however, that the President of the Senate shall count the votes. It says that the votes "shall then be counted," but it says nothing about who is supposed to do the counting. The President of the Senate is not even necessarily the most plausible candidate for that job, given both the text's clear commitment of the certificate-opening function but not the vote-counting function to the President of the Senate and the structural oddity of having the President of the Senate, who is quite possibly going to be directly interested in the outcome of the presidential election, given control over the counting process. ${ }^{8}$ It is not impossible to read the Twelfth Amendment to vest the counting function in the President of the Senate, but it is not the only reading that immediately commends itself.

Well, if not the President of the Senate, then who? The only other legal actors mentioned in the relevant provision of the Twelfth Amendment are the

8 See Colvin \& Foley, supra note 7, at 481; Kesavan, supra note 6, at 1705. 
members of the Senate and the House. Does the joint assemblage of the Senate and House therefore count the votes? That would seem to be the default answer once one rules out the President of the Senate, but the text and structure of the Twelfth Amendment does not immediately suggest vesting the counting function in the collective body of assembled representatives (which, among other things, would leave unstated the mechanism by which this collective body is supposed to perform a counting function). One could run a textual and structural argument similar to the one made above regarding the Vice President for the assembled members of the Senate and House, who are textually given certain functions but not explicitly assigned the counting function and who might well have personal and/or partisan interests in the electoral outcome, perhaps leaving one with the President of the Senate as the default counter.

Yet a third possibility is that the House has the counting function for the presidency and the Senate has the counting function for the vice presidency. That is because if no one has a majority of the electoral votes after they are counted, the House chooses the President from among the top vote-getters "not exceeding three on the list of those voted for as President," and the Senate chooses the Vice President "from the two highest numbers on the list." The House and Senate thus must have some way to determine (1) whether anyone got a majority of the electoral votes and, if not, (2) who were the top vote-getters. It is not textually impossible to see that counting function vested in the bodies that must act (or not act in the case of an electoral majority) on the basis of that count, though it would be an odd provision that locates the counting function, sub silentio, in the very last bodies to show up in the text.

For those who regard early practice as informative, or even dispositive, for resolving constitutional ambiguities: On February 6, 1789, a President of the Senate was elected "for the sole purpose of opening the certificates, and counting the votes of the electors of the several States in the choice of a President and Vice-President of the United States ... " "9 The same thing happened on February 13, 1793 except that in 1793, the Houses of Congress each appointed tellers to assist the Vice President, and possibly do the actual tallying of the votes. ${ }^{10}$ In 1789 , according to the Annals of Congress, the President of the Senate opened and counted the electoral votes. In 1793, the certificates were opened and read by the Vice President, serving as President of the Senate, and tellers appointed by the two Houses of Congress apparently tallied them ("ascertained the votes") and presented the list to the Vice President who then read the list aloud and declared the winners of the election. ${ }^{11}$

\footnotetext{
91 AnNals of Cong. 17 (Joseph Gales, ed., 1790).

10 See 3 ANNALS OF CONG. 874 (1793).

11 See 3 ANNALs of CoNG. 874 (1793).
} 
The early practice was thus to treat the President of the Senate (who could not be the Vice President in 1789 because there was not yet a Vice President) as the proper counting authority or at least as the supervisor of the count. And in 1792, in the first general statute regulating the counting of electoral votes and specifying presidential succession (in case there is neither a President nor a Vice President), Congress equated the opening of the certificates, which the Constitution tells us is to be done by the President of the Senate, with the counting of the votes, on which the text of the Constitution is silent. ${ }^{12}$ We do not here endorse any particular answer to this vexing ambiguity regarding who counts the electoral votes. For present purposes, we can leave that ambiguity unresolved; in 2021, we do not think that anyone was arguing about the math.

The lingering question from the text of the Twelfth Amendment is what happens if there is a dispute over the validity of a document that purports to be a State's electoral vote certificate or, as happened in 1876, multiple people claiming authority under state law provide the President of the Senate with competing certificates. Put another way, what is the meaning of the term "certificates" (or the prior term "lists of all persons") as it is used in the Twelfth Amendment? Sadly, the Twelfth Amendment does not say. In what might seem a heresy in light of the near religious devotion many Americans have to the Constitution, in this regard the Constitution is defective. This should not be seen as a serious criticism of the people who framed the Twelfth Amendment, for their task was necessitated by a defective Article II, section 1 , clause 3 , which failed to provide a method for separately selecting a President and Vice President and resulted in the election of political enemies in one election and the possibility of a tie for President between a party's presidential and vice-presidential candidate. ${ }^{13}$ Designing an indirect method of electing a chief executive turns out to be more complicated than it might initially appear.

In our view, the only constitutionally sound answer to the lingering question is that the Vice President must decide whether to include a submitted document as a "certificate" in the tally and, in the case of multiple submissions, select the one that in his or her opinion represents the State's electoral votes. This must be understood in light of the Twelfth Amendment's clear command that the votes signed and certified by state electors "shall then

12 See An Act relative to the Election of a President and Vice President of the United States, and declaring the Officer who shall act as President in case of Vacancies in the offices loth of President and Vice President, 1 Stat. 239 (1792) ("the said certificates, or so many of them as shall have been received, shall then be opened, the votes counted ...."). This statute remained in effect until it was repealed by the predecessor of the current Electoral Count Act. See The Electoral Count Act of 1887, Pub. L. 49-90, 24 Stat. $373(1887)$.

13 See Bruce Ackerman, The Failure of the Founding Fathers: JefFerson, Marshall, AND THE RISE OF PRESIDENTIAL DEMOCRACY (2005). 
be counted." This leaves the Vice President with little if any discretion, but in case of a dispute that must be resolved, in our view the decision falls to the Vice President as the official assigned the task of opening the certificates and presiding over the process. Any determination by the Vice President is then subject to scrutiny in federal court in a case brought by a candidate who loses the election due to the Vice President's decisions. In fact, the Vice President's tally even in an undisputed election is theoretically subject to judicial review, although in most election cycles no non-frivolous case could be brought.

There are numerous reasons why neither House of Congress has any role to play in determining the validity of state certificates. First, and most obviously, the text of the Constitution already assigns to the House and the Senate two roles: to witness the Vice-President's count and to elect the President and Vice President in case no candidate garners a majority. This may be the easiest application of the expressio unius canon of construction of all time because, as the Supreme Court emphatically recognized in the Chadha ${ }^{14}$ decision, unless the Constitution specifies otherwise, Congress may not take action having binding legal effect without presenting its decision to the President for signature or veto. A concurrent resolution by Congress rejecting or accepting a particular electoral vote certificate would be a blatant violation of Chadha and the rather clear terms of Article I, section $7 .{ }^{15}$

Second, the Constitution's specification that the House votes State by State when, in cases of no electoral vote majority, it elects the President supports the notion that, under the Constitution, an ordinary vote of the House of Representatives should play no role in the election. When the House elects the President, it is representing the States, not the people. By design, State by State voting is much more likely to be unrepresentative ${ }^{16}$ than a vote in which each Member of the House has an equal vote. For example, in recent years, one of the two major parties (Republican) typically has a majority in more state delegations than the other party (Democratic), even when there are more

14 INS v. Chadha, 462 U.S. 919 (1983).

15 More precisely, such a resolution would have no legal effect. Congress by concurrent resolution can say anything that it wishes, whether it be rejection of a state electoral certificate or a declaration of National Potato Month. Without presentment, however, those words are just words.

16 Lawson is prepared to go along with the use of the word "unrepresentative" in this context because it is standard terminology. He points out, however, that it assumes that population-based representation is the default position, so that forms of representation based on geography, interests, economics, or anything other than numbers are, by definition, "unrepresentative." He thinks that is mistaken; one is choosing among forms of representation rather than choosing between representation and something else, and he sees neither a constitutional nor a normative case for automatically favoring numbers over all other competing notions of representation. See Gary Lawson, No History, No Certainty, No Legitimacy . . No Problem: Originalism and the Limits of Legal Theory, 64 FLA. L. REV. 1551, 1567 n.51 (2012). But Lawson is a crackpot, so the hypothetical joint author known as "Beermann \& Lawson" will squelch that Lawson joker for the time being. 
Democrats in the House than Republicans. House Democrats often receive substantially more votes overall than their Republican counterparts. The constitutional design makes that irrelevant when the House selects the President, purposely giving the least populous States a voice equal to that of the most populous. It is extremely unlikely that the Framers would have carefully constructed this unrepresentative system while, at the same time, allowing an ordinary vote in the House of Representatives to determine the outcome of the election, albeit through a different procedure.

Third, congressional assumption of a role in the electoral vote count would be structurally inconsistent with the method of presidential election specified in the Constitution. The Constitution assigns to each state legislature the authority to determine how to select its electors. At present, all States employ elections, in which eligible voters indicate their presidential preference, which results in the election of state electors pledged to the winning candidates. States also have freedom to choose between a winnertake-all system in which the winning candidate receives all of the State's electoral votes and other reasonable systems such as allocating electoral votes proportionally or according to a geographic distribution such as by congressional district. But that is not the only permissible system. It might be done directly by the state legislature, with or without presentment to the state governor. It might be done by statewide convention or in local caucuses.

Importantly, the Constitution does not specify a process for resolving disputes over the selection of electors. The most reasonable inference from this silence is that it is up to each State to resolve any such disputes regarding its electors, subject only to two requirements, that electors are selected "as the [State] Legislature thereof may direct" ${ }^{\prime 17}$ and that the selection be done on time, i.e. quickly enough for the certificate to be in the possession of the Vice President when he or she conducts the tally of votes in the presence of Congress. We recognize that constitutional silence might leave the door open, even if just a crack, to federal legislation specifying a process for resolving such disputes, but even if this is so, we remain firm in our belief that Congress itself may play no role in the process of dispute resolution.

In sum, the Constitution does not assign to Congress any role in the process of ascertaining the winner in the tally of electoral votes (beyond a textually conceivable, though unlikely, role as a ministerial tabulator). What this means in light of the recent controversy over the 2020 election is that although the Constitution left him no discretion to reject electoral vote certificates provided by state electors, Vice President Mike Pence was the only appropriate federal target of efforts to invalidate electoral vote certificates in disputed states.

17 As explained below, we believe that the state Legislature must construct the dispute resolution procedure. 
Are we happy with our interpretation of the Constitution, that the President of the Senate (usually the Vice President) has the power, subject only to potential judicial review, to determine which electoral votes to count? It is, of course, an enormous power to place in one person's hands, but, as we have observed, the Constitution requires the counting of certificates provided by state electors, leaving the Vice President no discretion in the matter. Further, if past performance is indicative of future results, we are reassured by the fact that even in the most contentious transitions, the system has accomplished the goal of electing a President based on an accurate tally of the electoral votes transmitted by the states. ${ }^{18}$ Only twice, both long ago, in 1801 and again, in 1877, has the system produced serious doubts over whether the correct votes were counted. In 1801, Vice President Thomas Jefferson allegedly "counted himself into the presidency" by including the votes represented by a facially defective certificate from Georgia that placed him in a tie with Aaron Burr (both receiving a majority of the total with each elector casting two votes) for the presidency, resulting in a two-person runoff in the House of Representatives which Jefferson eventually won. Had Georgia's votes not been counted, the top five candidates receiving electoral votes would have been candidates in the House, which may have selected another candidate, less objectionable to those opposed to Jefferson. ${ }^{19}$ In 1877 ,

18 It was suggested to us that perhaps the Vice President should recuse herself if she is a party in interest, for example a candidate for re-election or for President. One could even make an argument that a self-interested Vice President constitutionally cannot act as the President of the Senate in such circumstances, by analogy to arguments that the Vice President cannot preside over impeachment trials of herself notwithstanding what seems like clear textual authority to do so. See AKHIL REED AMAR, AMERICA's UNWRITTEN CONSTITUTION: THE PRECEDENTS AND PRINCIPLES WE Live By 4-5 (2012). At least one of us has some generalized sympathy for such arguments, based on the idea that the Constitution incorporates by reference background principles of fiduciary law for its authorized actors. See GARY LAWSON \& GUY SEIDMAN, "A GREAT POWER OF ATTORNEY": UNDERSTANDING THE FIDUCIARY CONSTITUTION (2017). Unlike with impeachment, however, in the case of the Twelfth Amendment the Vice President is likely to be interested in the proceedings as a matter of course rather than rarely or episodically, so the Twelfth Amendment's entrustment of the task to the Vice President seems like an express overriding of any background fiduciary rules. We note that even in bitterly contested elections, most notably in 2021 when candidate for re-election Vice President Mike Pence presided over the process and in 2001 when presidential candidate Vice President Al Gore presided over the process, the Vice President has always counted the certificates provided by the States. In 1801, the Vice President may have erred by counting a defective certificate that gave him an advantage in the election, see infra, but no Vice President has ever refused to count a certificate provided by a state's electors.

19 See Bruce Ackerman \& David Fontana, Thomas Jefferson Counts Himself into the Presidency, 90 VA. L. REV. 551, 566 (2004) (citing U.S. CONST. art. II, § 1, cl. 3, amended by U.S. CoNST. amend. XII). The charge against Jefferson might not be justified because the tellers may have believed that the Georgia certificate satisfied the requirements of both the Act and the Twelfth Amendment, and it may have been the tellers' decision, not Jefferson's, to count the votes. The Journal of the Senate states that "the certificates ... were, by the Vice President, opened and delivered to the tellers appointed for the purpose, who, having examined and ascertained the number of votes, presented a list thereof to the Vice President, which was read, as follows." The list included Georgia's votes, and the wording implies both that the tellers decided that Georgia's certificate was proper and that Jefferson may have been unaware of any irregularity. Thanks to John Harrison for pointing this out. See 10 ANNALS OF CONG. 743-44 (1801). 
Congress wrested the determination from the hands of the President of the Senate and handed it to a partisan commission that included ten Members of Congress. Perhaps a better system could be devised, one that would guarantee the maximal adherence to the ideal of accurate tabulation of state electoral votes, but in the meanwhile, we rest assured that this aspect of the system has, as we understand it, left our electoral system "virtually spotless."

\section{B. Disputes over Voter Fraud}

President Trump and his supporters made two distinct attacks on the 2020 presidential election: first, that Joe Biden's victory was the result of massive vote fraud in some States and, second, that state officials other than the legislature changed the rules for conducting the election, in violation of the Constitution. We discuss disputes related to voter fraud here; the issue of state deviation from legislatively-prescribed election procedures is discussed below.

In our view, neither Congress nor a federal agency has a constitutional role to play in resolving disputes over voter fraud in the presidential elections, and any potential role for the federal courts arises only after the Vice President conducts the tally of electoral votes. ${ }^{20} \mathrm{We}$ explain each conclusion in turn.

The lack of a role for Congress follows directly from our preceding analysis. The Constitution specifies that electors are selected "as the [State] Legislature thereof may direct." This must include construction of processes for resolving disputes over the election, because otherwise Congress could coopt the process simply by allocating to itself or some other federal entity authority to resolve such disputes under standards prescribed by Congress or that entity. For example, imagine that Congress granted the Federal Electoral Commission power to conduct binding adjudications of claims alleging that a State's electors had been chosen pursuant to a fraudulently conducted election. Either Congress or the Commission would have to determine what constitutes fraud, and one of them would have to specify the remedy for a finding of fraud. If a State's electors were replaced due to a ruling by the commission, those electors would have been chosen as specified by Congress, not as specified by the state legislature, a clear violation of the Constitution. Even more clearly, the same would be true if electors could be rejected or replaced by Congress itself. In such cases, Congress's standards for choosing electors would necessarily and unconstitutionally override state

20 We do not explore whether a federal court might exercise diversity jurisdiction over a case brought against state officials by a candidate from a different State. Such a suit would raise numerous questions including state sovereign immunity under the Eleventh Amendment, abstention, and the political question doctrine. 
legislative choices concerning the selecting and challenging of electors. Even if Congress claimed that it was merely applying the standards prescribed in state law, or if it instructed a federal agency to apply such standards, Congress would have seized state authority to create the method of dispute resolution and, more fundamentally, state control over the interpretation of the text of state statutory requirements. (This conclusion is elaborated below when we address state deviation from the apparent requirements of state election laws.)

Perhaps even more basic than this structural argument is the notable absence of any enumerated congressional power to regulate the process of selecting presidential electors. Congress is specifically granted constitutional power to alter state rules regarding " $[t]$ he Times, Places and Manner of holding Elections for Senators and Representatives," ${ }^{21}$ but there is no comparable enumerated power with respect to the process for choosing presidential electors. And one need not adhere to a conception of the Necessary and Proper Clause ${ }^{22}$ as constraining as Professor Lawson's ${ }^{23}$ to see that there is no federal power for Congress to carry into execution in this context. State legislatures are not "the Government of the United States, or ... any Department or Officer thereof," so Congress cannot pass laws for carrying into execution their constitutionally vested powers.

The absence of provisions granting Congress the power to regulate presidential elections highlights another reason for rejecting a role for Congress in determining the validity of electoral votes. The Constitution created a system of separation of powers with checks and balances. Subjecting electoral votes to congressional supervision could eviscerate the President's ability to check Congress because incumbent Presidents seeking reelection, and even first-time presidential candidates, would need to show sufficient loyalty to Congress to avert rejection of their electoral votes. Further, although party politics may not have been anticipated by the Framers, in operation, the Constitution allows for the election of a President of a party other than the one that controls Congress. This is often cited as a constitutional virtue by those who view "divided government" as a way to combat excessive governmental zeal. Allowing Congress the power to reject electoral votes and send the presidential election to the House would imperil the voters' ability to opt for divided government. There are many countries in the world in which divided government is virtually impossible; the United States is not one of them.

21 U.S. CONST. art. I, § 4, cl. 1.

$22 I d$. art. I, $\$ 8$, cl. 18.

23 See Gary LaWson \& GUY SEIDMAN, "A GREAT POWER OF ATTORNEY": UNDERSTANDING THE Fiduciary Constitution 76-103 (2017); Gary Lawson \& Patricia B. Granger, The "Proper" Scope of Federal Power: A Jurisdictional Interpretation of the Sweeping Clause, 43 DUKE L.J. 267 (1993). 
Even a simple federal statute requiring, for example, that States use paper ballots or not use a type or brand of voting machine subject to control by the deceased leader of a South American dictatorship would be unconstitutional. The Constitution is clear. States prescribe the method of selecting state electors, and absent a violation of a voting-related provision of the Constitution, such as the federal constitutional provisions prohibiting the denial of the vote based on race, sex, ability to pay a poll tax, or age of eighteen or greater, ${ }^{24}$ federal law may not alter state standards. ${ }^{25}$

So how exactly are disputes over voter fraud and related challenges supposed to be resolved? It's really simple. They are resolved however the state legislature says they are supposed to be resolved. Those resolution processes - as well as the non-obvious determination of what constitutes fraud ${ }^{26}$ - are part of the "Manner" of selecting electors that state legislatures prescribe. The state legislature could assign such challenges to a state court, to a state agency, to a single state official such as the governor or the secretary of state, or to itself (or a subunit of itself). If the designated forum is not a state court, it is up to the state legislature to determine whether a non-judicial decision on the validity of the election is subject to judicial review in state court. One can question the wisdom of various choices of state legislatures in this regard, but, absent violation of a specific constitutional prohibition, one cannot question the legality of those choices. ${ }^{27}$

24 See U.S. Const. amends. XV, XIX, XXIV, XXVI.

25 This conclusion opens a window into a complicated and open legal question of whether a more general constitutional standard like equal protection or due process might provide a basis for judicial or congressional intervention into state voting standards. The text of the Fourteenth Amendment, specifically its provision allowing for reduction of state representation in the House when a State unlawfully denies a class of persons the right to vote, indicates that they do not. See id. amend. XIV, $\S 2$. This indirect supervision of state voting practices indicates that the Framers of the amendment did not believe that the amendment's enforcement power provides a basis for direct regulation of state voting rules. It is also conceivable that the Guarantee of a Republican Form of Government Clause, could authorize, and even require, federal intervention in state voting practices that are so egregious that they violate the norms of republicanism, though it is not clear from the provision which federal institutions would have what kinds of powers or responsibilities in those circumstances - and never mind what it might mean for institutions to be "republican." See id. art. IV, § 4; STEVEN GOW CALABRESI \& GARY LAWSON, THE U.S. Constitution: Creation, Reconstruction, the Progressives, and the Modern ERA 77-78 (2020).

26 Is it "fraud" if ballots are cast, multiple times, in the name of dead former residents of Chicago? In the selection of presidential electors, that is actually up to the Illinois state legislature to decide. U.S. CoNST. art. II does not embody a platonic conception of fraud. Something is only fraud if it deviates from a baseline of legality, and the Constitution commits the specification of that baseline to state legislatures in the case of selection of presidential electors.

27 Could any of those constitutional prohibitions be implicit rather than explicit? That depends on one's theory of constitutional interpretation. (And even the most ardent of textualists will often recognize some implicit provisions, such as fiduciary background rules.) The point here is only that there needs to be some constitutional norm outside U.S. CoNST. art. II, §1 on which to ground any legal challenge. 
So now let's assume that state processes have run their course, and there is substantial evidence that something fishy-by the standards of the State's own processes-went on. If the State sends a certificate that reeks of rotting aquatic life, must the Vice President include the votes represented by the certificate in the tally?

Here, there is some constitutional uncertainty. The language of the Twelfth Amendment says nothing other than that the Vice President is supposed to "open all the certificates and the votes shall then be counted." It may be that this leaves the Vice President no choice but to open and count all certificates purporting to have been provided by the State's electors, ${ }^{28}$ even if it is widely known, for example, that the candidate named in the certificate did not receive a single lawful vote in the State. ${ }^{29}$ This is what Vesan Kesavan calls a "thin" conception of counting, in which counting is a ministerial function with no element of judgment. ${ }^{30}$ The language of the Twelfth Amendment ("the votes shall then be counted") certainly supports this reading. There is also, however, a credible constitutional argument for a "thicker" conception of counting under which the Vice President has the unilateral authority to decline to include a certificate-or purported certificate that does not meet some objective constitutional criterion for being a legitimate "certificate"-in the count. ${ }^{31}$ Support for this argument lies in the possibility that the Vice-President might receive more than one certificate purporting to be genuine and authoritative from a State in which its own authorities did not resolve the dispute or in which two different resolutions were arrived at by competing state authorities. Far-fetched? No more farfetched than the prospect of two (or conceivably more) sets of forces both claiming to be the legitimate government of a State. ${ }^{32}$ Recall that in the 1876 election, the President of the Senate received multiple electoral vote certificates from persons claiming to be the legitimate authorities from the States of Florida, Louisiana, and South Carolina. In such circumstances,

28 See Kesavan, supra note 6, at n.220 (so arguing with respect to opening of certificates).

29 This could happen if the National Popular Vote Interstate Compact went into effect through enactment by a sufficient number of States (and approval by Congress if it is considered the sort of compact that Congress must approve), and the candidate receiving the most popular votes did not qualify to appear on the ballot in a state that joined the compact. See Agreement Among the States to Elect the President by National Popular Vote, NATIONAL POPUlaR VOTE, https:/www.nationalpopularvote.com/written-explanation (last visited Feb. 28, 2021). States adopting that proposal would agree to cast their electoral votes for the winner of the national popular vote regardless of the outcome of the election in their own State. By its terms, the compact would become effective only if States representing a majority of electoral votes had passed it. Interestingly, the compact might be effective for one or two elections and then go out of effect if the distribution of electoral votes pursuant to the decennial census deprives the compacting states of a previously-held majority of electoral votes.

30 See Kesavan, supra note 6, at 1712-13.

31 See Harrison, supra note 1 , at 703.

32 See Luther v. Borden, 48 U.S. 1 (1849). 
someone has to decide which (if any) certificates to count, and in our view, the only likely candidate for this task is the Vice President. As described above, Congress cannot perform this function. Perhaps the House, voting State by State, could perform that function for the President and the Senate could perform it for the Vice President, but that requires several textual leaps beyond simply folding the function into the President of the Senate's duty to open "certificates" coming from "Electors" but only "certificates" coming from "Electors." It would be impossible to have a rule that in a State providing multiple certificates, no certificate may be counted, because that would give each political party or faction an easy method of nullifying the States' votes. Moving along, if the Vice President has the authority to choose among competing certificates (or, viewed another way, among competing claimed "Electors"), then he or she might also have the power to reject a certificate for some other reason, such as evidence of voter fraud or, perhaps, a State's failure to comply with its own election laws, on the rationale that documents coming from people who claim to be "Electors" are not from the real, constitutionally valid "Electors" mentioned in the Twelfth Amendment.

Would the Vice President's power to select among competing certificates/electors or to reject a certificate for some other reason be final and conclusive? We think not. In our view, the Vice President's actions would be subject to challenge in federal court on the ground that his or her rejection of a certificate was illegal or not supported by the facts. The grounds for challenge would be confined to federal law and would depend on the Vice President's grounds for rejecting the certificate. For example, if the Vice President determines that a certificate from a State had not been actually sent by the States' electors, the court would have authority to review the facts to determine whether that was true. This determination might require an inquiry into state law, because the purported electors who sent the certificate likely had some legal basis for their belief that they were the electors vested with authority to cast votes for President; a certificate sent by a persons or persons other than the state's electors would be of no effect under the Twelfth Amendment.

What would happen if the Vice President rejected a certificate based on his or her conclusion that the State's election was infected by fraud? In our view, for reasons described above, this would not be proper legal grounds for rejection: disputes over the conduct of a State's election must be resolved on state law grounds and pursuant to the method specified by the state legislature. The Vice President has no constitutional authority to impose standards of conduct on state-administered selection procedures for electors. Unless the Vice President identifies a violation of federal law, or determines that a certificate was not provided by a State's electors, all votes contained in the certificates must be counted. 
We recognize that the federal courts might be reluctant to get involved in what is likely to be a politically charged controversy over the Vice President's administration of the Twelfth Amendment. It is even conceivable that the Supreme Court would decide, contrary to our view, that the Vice President's actions are not subject to judicial review, perhaps based on the political question doctrine, a theory of equitable discretion, or on the view that the Vice President owes no duty to individual candidates. We note, however, that many of President Obama's and President Trump's most controversial actions were subjected to federal court review, including several in the highly-charged immigration context, this despite the Supreme Court's prior determination that the President is not an agency subject to review under the Administrative Procedure Act. ${ }^{33}$ It would seem inconsistent with the theory of separation of powers with checks and balances to shield the Vice President's electoral vote decisions from judicial review, especially when it is clear that Congress has no role to play in the matter. ${ }^{34}$ And even if we are incorrect, and the federal courts would not review the Vice President's determinations over the validity of state electoral vote certificates, the mandatory nature of the Twelfth Amendment's command that the votes "shall then be counted" and the tradition of Vice Presidents' adherence to their constitutional duty should be comforting to anyone concerned over this.

In sum, disputes over the conduct of the election may be resolved only as specified by the state legislature. Congress most likely has no constitutional role in the process of counting electoral votes, and all certificates transmitted to the President of the Senate must be included in the count unless the Vice President concludes that a certificate was not transmitted by a State's electors or that it is invalid due to some other violation of federal law. The Vice President's decisions concerning the validity of the certificates is subject to challenge in federal court, but judicial review must be narrowly focused on whether, under the facts and the law, federal law has been violated. The federal courts should not allow the Vice President to reject certificates based on findings of election fraud or illegal voting without evidence of a violation of one of the federal constitutional requirements governing the election, such as the requirement that electors be chosen as specified by the state legislature or that the document reporting the

33 See Dalton v. Spencer, 511 U.S. 462, 476 (1994); Franklin v. Massachusetts, 505 U.S. 788,801 (1992).

34 Lawson, for his part, is dubious that the Supreme Court has the power, under whatever label, to refuse to decide a case within its enumerated constitutional jurisdiction just because a bunch of justices think it is too touchy. Beermann once expressed a similar view in the context of abstention. See Jack M. Beermann, "Bad" Judicial Activism and Liberal Federal Courts Doctrine: A Comment on Professor Doernberg and Professor Redish, 40 CASE W. RES. 1053 (1990). But see supra note 16 (explaining "Beermann \& Lawson's" general attitude towards that Lawson fellow). 
State's results be signed and certified by the State's electors and transmitted by them to the President of the Senate.

While some of the conclusions that we have just reached are subject to reasonable dispute, some are not. That, of course, does not prevent Congress from reaching unreasonable conclusions. And Congress, true to form, has not disappointed. We now turn to an examination of the Electoral Count Act, which represents Congress's construction of its role under the Twelfth Amendment.

\section{The Electoral COUNT ACT}

In the disputed election of 1876 , Democratic Party candidate Samuel Tilden received 184 undisputed electoral votes, one short of the required 185 to be elected President. Republican Rutherford B. Hayes received 165 undisputed votes, and 20 votes were disputed. Nineteen of those votes represented Florida, South Carolina, and Louisiana, where multiple certificates had been transmitted to the President of the Senate, and one vote, from Oregon, was disputed because the State's governor replaced a Republican elector who had been ruled ineligible to serve with a Democrat. Tilden needed to win only one of the disputed electoral votes to become President, while Hayes needed all twenty.

Congress legislatively established a commission to resolve the dispute. The fifteen-member commission, composed of Members of Congress and Supreme Court Justices, was supposed to include seven Republicans and seven Democrats with independent Supreme Court Justice David Davis of Illinois presumed to be holding the deciding vote. While the commission was being put together, the Republican-controlled Illinois legislature, in order to engineer a Republican majority, elected Davis to the United States Senate, which left only Republicans on the Supreme Court to fill the fifteenth seat. This resulted in 8-7 votes in favor of Hayes with regard to every disputed electoral vote, making Tilden the only candidate in U.S. history to win a majority of the popular vote and not become President.

It took Congress until 1887 to craft and pass a general statute, the Electoral Count Act,${ }^{35}$ to provide a method for resolving disputes like the one that occurred in 1876 . The Act as presently codified, in large part, tracks the requirements of the Constitution, such as stating how many electors each State is entitled to appoint ${ }^{36}$ and that after they vote, the electors must sign and certify the certificate and send a copy thereof to the President of the

35 Act of Feb. 3, 1887, ch. 90, 24 Stat. 373. The modern version was codified as part of the enactment of Title 3 of the United States Code into positive law. See Act of June 25, 1948, ch. 644, 62 Stat. 672 (codified at 3 U.S.C.).

36 See 3 U.S.C.S. $\$ 3$ (LEXIS through Pub. L. No. 117-21). 
Senate. ${ }^{37}$ The Act also specifies the date of the election ${ }^{38}$ and the time for the meeting of the electors, ${ }^{39}$ both of which Congress is authorized to set by Article II of the Constitution. ${ }^{40}$ However, some of the Act's provisions go well beyond the Constitution and, in some cases, may contradict constitutional requirements. Before arguing that parts of the Act are unconstitutional, we first explain how the Act's process for objecting to electoral votes was misapplied on January 6, 2021.

The Act's central provision ${ }^{41}$ tracks the procedure adopted in the 1877 Electoral Commission Act, except that it omits the provision creating a federal commission to resolve disputes over States that transmit more than one certificate. The Act specifies that after the Vice-President opens each State's certificate and announces the State's votes, he or she "shall call for objections, if any." Then, if an objection is made in writing and signed by at least one Member of the House and one Member of the Senate, the House and Senate shall separately debate and vote on the objection, and if both Houses vote in favor of the objection, the electoral votes from that State shall not be counted. Vice-President Pence scrupulously followed that process, but he, and the Members of Congress generally, ignored the Act's substantive limitation of objections, that:

$[\mathrm{N}]$ o electoral vote or votes from any State which shall have been regularly given by electors whose appointment has been lawfully certified to according to section 6 of this title [U.S. Code Title 3] from which but one return has been received shall be rejected, but the two Houses concurrently may reject the vote or votes when they agree that such vote or votes have not been so regularly given by electors whose appointment has been so certified. ${ }^{42}$

In other words, any objections that Congress may legally make to electoral vote certificates must concern whether the certifying authority of the State complied with section 6.

The relevant requirements of section 6 are three: the communication of the identities of the electors by the State's executive authority to the National Archivist, inclusion in the list of electors the vote totals underlying their selection, and, in case a dispute arose concerning the identities of a State's electors (presumably including a dispute over the outcome of the election),

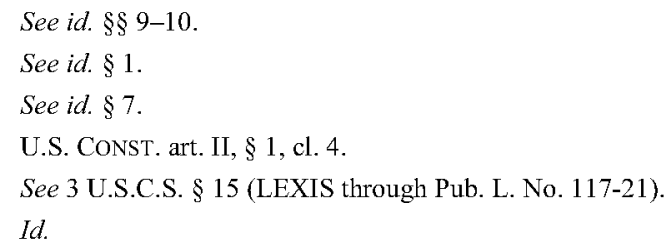


certification by the State executive of the result of the dispute. ${ }^{43}$ The objections by Members of Congress to the electoral vote count on January 6 , 2021, were based on vote fraud and alleged failure of States to adhere to state election procedures are thus are not contemplated by the text of the Electoral Count Act. Acceptance of those objections by a majority in Congress would thus have been statutorily unlawful, in addition to an unconstitutional usurpation of the Vice-President's role in the electoral vote count.

While the language of section 15 is turgid, our view that fraud and other state election irregularities are not statutory bases for objecting to electoral vote certificates is supported by the history of the 1876-77 dispute that inspired the Act. ${ }^{44}$ The Electoral Commission that Congress established to resolve the disputes over the 1876 election refused, over strenuous objections by the lawyers for Democratic Candidate Samuel Tilden and by party-line vote, to look behind the certificates provided by the governors of Florida, Louisiana, and South Carolina. Instead, although it allowed Tilden's lawyers to present evidence of election fraud and intimidation, it viewed its task as confined to determining which certificates had been provided by the legitimate governor of each of the States. Once the commission decided that the governor in each of the disputed States was the Republican, the commission concluded, again by party-line vote, that it would award the disputed States' electoral votes to Hayes as specified in the certificates forwarded by the electors identified by the Republican governors.

The commission did, however, deviate from this practice with regard to Oregon. In Oregon, the Democratic governor had replaced an ineligible Republican elector with a Democrat, thus potentially awarding one of the State's electoral votes to Tilden despite Hayes having indisputably won the Oregon election. In this case, the commission peeked behind the certificate and decided that the Democratic governor could not replace the Republican elector with a Democrat even though the governor had acted in accord with the requirements of State law. This provoked a strong dissent from a Democratic member of the commission, which confirms that with regard to the other States, the commission did not look behind the certificates:

By a vote of eight to seven, this Commission has decided on purely technical grounds that Florida, Louisiana and South Carolina voted for Hayes, and by the same vote of the same members have, as I think, discarded these very same technical grounds to give the one disputed vote of Oregon to Hayes. I say this Commission has disappointed public expectation because the country expected of it that it would

43 See id. $\$ 6$

44 For a detailed account of that history, see Colvin \& Foley, supra note 7. 
decide who had been elected President and Vice-President by the people. They did not expect of us that we would merely confirm the judgment of corrupt and illegal returning-boards who in effect put the presidency up to the highest bidder in the public market. ${ }^{45}$

Because the current Electoral Count Act does not provide a legal basis for overruling the Vice President's decision to count the electoral votes from Arizona and Pennsylvania, the objections should not have been entertained. Ordinarily, it might make sense to allow a pointless debate to go forward, if only to allow Members of Congress with strong feelings to have their say. In fact, many debates in Congress appear to us to be pointless. But on January 6 , the delay served to give aggressive members of the mob outside the Capitol Building time to stage their attempt to prevent the electoral vote tally from going forward, presumably to pave the way for a reversal of the election and, in effect, a coup. ${ }^{46}$ The process should have been over in a half hour, and the Members of Congress might have escaped before the mob forced them to shelter in confined quarters with colleagues who, by refusing to wear masks, likely exposed them to the COVID-19 virus.

Of course, even if the Act had purported to allow Members of Congress to cancel out a State's electoral votes based on concerns about the State's selection process, it would be unconstitutional, for reasons that we have elaborated above, including the clear implication from congressional power to alter state rules for electing Members of Congress that it has no role in crafting rules regarding the selection of presidential electors. Congress's attempt in the Act to give itself a role in resolving disputes over electoral votes is perhaps the best example of Madison's prediction in Federalist 48 that " $[t]$ he legislative department is everywhere extending the sphere of its activity and drawing all power into its impetuous vortex." 47 Just as the Supreme Court turned away Congress's attempt to appoint members to the Federal Election Commission (because the Appointments Clause prescribes

45 See Gov't Printing OfF., The Electoral Count of 1877: Proceedings of the ELECTORAL COMMISSION AND OF THE Two Houses of CONGRESS IN JOINT MEETING RELATIVE TO THE Count of Electoral Votes Cast December 6, 1876, For the Presidential Term Commencing MARCH 4, 1877, 929-30 (1877) (statement of Commissioner Eppa Hunton).

46 Does the phrase "pave the way for a reversal of the election and, in effect, a coup" mean that reversal of the election would amount to, in effect, a coup, or does it mean that stopping the allegedly unlawful electoral tally would pave the way for reversal of an election that was itself, in effect, a coup? Is it a blue and black dress or a white and gold dress? And, of course, the protestors may have had no ambitions of actually changing the electoral outcome. Sometimes protestors just gotta protest, and sometimes rioters just gotta riot. To be sure, there were probably not a lot of big-screen TVs to be lifted from the Capitol, so, as riots go, this one promised to be less remunerative than some others, but since neither of us has ever been part of a riot, we are not well equipped to analyze the motives of those who have.

47 THE FEDERALIST NO. 48 at 309 (James Madison) (Clinton Rossiter ed., 2003). 
only a limited congressional role-Senate confirmation-in the process), ${ }^{48}$ the Court should, in a proper case, reject the Act's provisions enabling Congress to supervise the counting of electoral votes and confine Congress to its constitutionally-prescribed role of electing the President and VicePresident in case no candidate receives a majority of electoral votes.

The Electoral Count Act contains additional constitutional infirmities. Before getting to them, we note that some of the Act's provisions are benign and fall comfortably within Congress's authority to enact laws that are "necessary and proper for carrying into Execution"49 the powers of the federal government. Several of the Act's provisions simply track the Constitution's requirements, such as recognizing each State's authority to provide by law for the replacement of electors unable to serve. In that respect, they are the legal equivalent of declarations of National Potato Month and make no change in the legal landscape. Another important provision requires each State executive to transmit the names of the electors to the Archivist of the United States. Under a broad view of the Necessary and Proper Clause, this could be seen to facilitate the Vice President's verification of the authenticity of the certificates transmitted by the electors themselves and thus is vital to the execution of the Twelfth Amendment, although we are not certain that Congress has the power to make a state executive's certification binding on the Vice President if, for instance, there is reason to believe that the governor is attempting to nullify the votes of the legally-selected electors. Further, a narrower view of the Necessary and Proper Clause sees that clause only as an authorization to allow Congress to help federal actors who are otherwise granted power to execute their own functions, not as authority to regulate non-federal actors to make the life of federal actors easier or to make the exercise of federal power more effective. Modern doctrine supports the former interpretation, but the matter is not entirely free from controversy. ${ }^{50}$ And the Act conveniently provides that the electoral votes will be opened by the President of the Senate on January 6 following the election, which plainly concerns the exercise of functions vested by the Constitution in a federal official and is thus easily constitutional.

Other provisions of the Act raise serious constitutional questions. We address two: section 5 of the Act provides that only state laws enacted prior to the election may conclusively determine disputes over the appointment of the electors and only if the results of the dispute are made at least six days

48 Buckley v. Valeo, 424 U.S. 1 (1976).

49 U.S. CONST. art. I, § 8, cl. 18.

50 See, e.g., Bond v. United States, 572 U.S. 844, 874-81 (2014) (Scalia, J., concurring in the judgment) (taking the narrower view with respect to execution of the federal treaty power); CALABRESI \& LAWSON, supra note 25 , at $841-42$. 
prior to the time of the meeting of the electors. ${ }^{51}$ This provision implies that state legislative enactments made after the election are not binding on the federal authorities engaged in the count of the electoral votes. In our view, disregarding state laws passed after the election would violate Article II's specification that States appoint their electors "in such Manner as the Legislature thereof may direct." ${ }^{52}$ And disregarding state dispute resolutions communicated less than six days prior to the meeting of the electors would unconstitutionally usurp state authority over the appointment of electors, because the implication is that some federal authority (Congress? The VicePresident?) would have power to resolve the dispute simply because the state dispute resolution process took a few days too long for Congress's tastes. In our view, this is absurd. Of course, if a State fails to appoint electors, the State's voters lose their voice in selecting the President and Vice-President. That would be a shame (unless, perhaps, one does not like the way that the State's electors were going to vote), but it would be consistent with the constitutional structure.

\section{UNCONSTITUTIONAL ELECTIONS}

In order to be constitutionally eligible to cast votes for President and Vice President, electors must be chosen "in such Manner as the Legislature" 53 of their State directs. How does a state legislature indicate that "Manner"? How do the federal officials responsible for counting the electoral votes determine whether people who claim to be electors really have that status?

Start with the first question. Interestingly, Article II of the Constitution does not specify any particular form through which state legislatures must express their chosen selection procedures. There are numerous additional references in the United States Constitution to action by state legislatures, such as selection of United States Senators, ${ }^{54}$ ratification of constitutional amendments, ${ }^{55}$ and consent to the formation of a new state that includes an

51 See 3 U.S.C. $\$ 5$ (2018) ("If any State shall have provided, by laws enacted prior to the day fixed for the appointment of the electors, for its final determination of any controversy or contest concerning the appointment of all or any of the electors of such State, by judicial or other methods or procedures, and such determination shall have been made at least six days before the time fixed for the meeting of the electors, such determination made pursuant to such law so existing on said day, and made at least six days prior to said time of meeting of the electors, shall be conclusive, and shall govern in the counting of the electoral votes as provided in the Constitution, and as hereinafter regulated, so far as the ascertainment of the electors appointed by such State is concerned.").

52 U.S. CONST. art. II, § 1, cl. 2.

53 Id.

54 U.S. CONST. art. I, $\$ 3$, cl. 1 (superseded by U.S. CONST. amend. XVII.) It appears that state governors were not involved in this process. See Wendy J. Schiller et al., U.S. Senate Elections Before the I7th Amendment: Political Party Cohesion and Conflict 1871-1913, 75 J. PoL. 835, 836-37 (2013).

55 U.S. CONST. art. V, $\S 1$. 
existing state's territory, ${ }^{56}$ and none of these references specifies the method by which the state legislature must act, including whether these actions are subject to veto by the state executive. By contrast, the Constitution often, but not always, specifies how Congress must act: for example, money can only be drawn from the federal treasury pursuant to appropriations made "by law," ${ }^{57}$ federal offices must be "established by Law," alter state rules for federal elections "by Law." ${ }^{59}$ Lawmaking, in turn, must follow the bicameral and presentment procedures laid down in Article I, section 7. On other occasions, the Constitution is less specific; each House, for example, "may determine the Rules of its Proceedings," 60 but the Constitution says nothing about how the House and Senate must go about establishing those rules. Each House also gets to "chuse" its officers (other than the constitutional specification of the Vice President as the President of the Senate) ${ }^{61}$ again with no specification of the method by which that must happen. The default rule, of course, is majority rule within each body, ${ }^{62}$ but if the majority chooses some method other than majority rule (perhaps picking the Speaker of the House by lottery), there is nothing legally invalid about following that procedure in a given case (though presumably the majority could change that procedure if it felt like it). If the Constitution demanded that the Speaker of the House, for instance, could be selected only by a vote of all of the Members, it would have been as easy to say so as it was to say that Congress can only act in specified ways by Law.

Article II is similarly silent about the means by which state legislatures establish the method for selection of electors. Whether a particular reference in the Constitution to state "legislatures" requires unilateral action by the legislature or implies that States may or must act in accordance with their state constitutional procedures for enacting statutes depends on context. ${ }^{63}$ When the Constitution assigned the ratification of constitutional amendments to state legislatures, this was considered a federal ratification function, not a state legislative function, and it was performed without observing state legislative formalities such as presentment to the state governor for signature or veto. ${ }^{64}$ Likewise, the election of United States Senators by state

$56 I d$. art. IV, $\$ 2$.

57 Id. art. I, § 9, cl. 7.

$58 I d$. art. II, $\S 2$, cl. 2.

59 Id. art. I, $\S 4$, cl. 1 .

$60 I d$. art. I, $\$ 5, \mathrm{cl} .2$.

61 Id. art. I, § 2, cl. 5; id. art. I, § 3, cl. 5.

62 See AMAR, supra note 18, at 56-63, 356-69.

63 See Ariz. State Legislature v. Ariz. Indep. Redistricting Comm'n, 576 U.S. 787 (2015) (state legislature may assign redistricting function to independent commission).

64 See Hawke v. Smith (No. 1), 253 U.S. 221 (1920). 
legislatures was performed without observance of state legislative procedures because it was an elective, not a legislative, function. ${ }^{65}$ However, the Supreme Court has held that the Constitution's Election Clause, which assigns to "the Legislature thereof" the function of regulating elections for "Senators and Representatives ... in each State" 66 assigns a typical legislative function that should be exercised in accordance with state legislative procedures. ${ }^{67}$ In our view, Article II, section 1's assignment to state legislatures of the power to determine the manner of selecting presidential electors is similarly a legislative power that we expect would be exercised in accordance with normal state legislative procedures. More to the point, for present purposes, is that the Court does not view express assignment of a power to state legislatures as necessarily implying a unique and unfettered power of the state legislature such that the state legislature's actions must be treated differently from other laws that the state legislature might pass. Thus, while perhaps state legislatures might establish presidential elector selection rules by a resolution that bypasses any state requirements of presentment to the governor, as they do with ratification of amendments to the federal Constitution, the fact that the words "by law" are not included in Article II's assignment of power to state legislatures is not dispositive.

As it happens, state legislatures typically put their selection procedures in the form of statutes. That is certainly their right under the Constitution. The only constitutional constraints on the substance of those selection procedures come from provisions limiting the ability of States to deny certain persons the right to vote if States choose to use voting as the means for selecting electors and whatever constraints flow from the Guarantee of a Republican Form of Government Clause, which might forbid, for example, allowing elector status to be hereditary.

Once those state legislatures' procedures ("Manner[s]") for choosing electors are in place, those state procedures acquire federal constitutional status. Only electors chosen in accordance with state legislatively prescribed procedures are the "Electors" mentioned in the Twelfth Amendment whose votes count towards election of the President and Vice President.

This basic fact is the foundation for many of the challenges arising from the 2020 election. In a number of States, voting rules were seemingly altered by executive and judicial officials. As claimed by the State of Texas in a

65 Ariz. State Legislature, 576 U.S. at 809.

66 U.S. CONST. art. $1, \S 4$, cl. 1.

67 In Arizona State Legislature, this provision was interpreted to include state legislative power over redistricting, and the Supreme Court upheld Arizona's statute that delegated the redistricting function to an independent commission. Ariz. State Legislature, 576 U.S. at 787. 
motion for leave to file in the United States Supreme Court (which was denied by the Court for lack of standing ${ }^{68}$ ):

Using the COVID-19 pandemic as a justification, government officials in the defendant states of Georgia, Michigan, and Wisconsin, and the Commonwealth of Pennsylvania (collectively, "Defendant States"), usurped their legislatures' authority and unconstitutionally revised their state's election statutes. They accomplished these statutory revisions through executive fiat or friendly lawsuits, thereby weakening ballot integrity.

...

By purporting to waive or otherwise modify the existing state law in a manner that was wholly ultra vires and not adopted by each state's legislature, Defendant States violated not only the Electors Clause, U.S. CONST. art. II, $\S 1$, cl. 2, but also the Elections Clause, id. art. I, $\S 4$ (to the extent that the Article I Elections Clause textually applies to the Article II process of selecting presidential electors). ${ }^{69}$

Assume for the moment that election procedures in at least some of the instances detailed in the Texas complaint were inconsistent with what appears to be the plain language of relevant state statutes in the named jurisdictions. Does that mean that electors in those States were unconstitutionally chosen in a manner different from the one prescribed by the state legislatures?

The short answer is "we dunno," and we suspect that no one else really knows either. The underlying legal question is how one ascertains the directions issued by the state legislatures in these instances. One way to ascertain those directions, of course, is to read the plain meaning of the statutes. As anyone moderately familiar with American law can attest, however, that is hardly the only means by which statutory language and legal instructions get matched up. ${ }^{70}$ If that was not so, law school Legislation and Administrative Law courses would be much shorter and more boring. Could it be the case, for instance, that the best way to ascertain the instructions for selecting electors prescribed by the Pennsylvania legislature is to look to see what would best promote the widest possible scope for voting in the face of unusual conditions, even at the potential cost of a measure of ballot security? How would one determine whether that is the case? A devotee of plain

68 See Texas v. Pennsylvania, 141 S. Ct. 1230 (2020).

69 Motion for Leave to File Bill of Complaint at 1, 14, Texas v. Pennsylvania, 141 S. Ct. 1230 (2020) (No. 220155).

70 See Linda Jellum, MAStering Statutory INTERPREtation (2d ed. 2013). 
meaning would answer: "By reading the statutes, dummy." But has the Pennsylvania legislature directed that its statutes regarding the selection of electors are supposed to be read strictly in accordance with their plain meaning?

Put another way: Is there anything in the United States Constitution that dictates to the States how state statutes governing the selection of presidential electors must be written, construed, or applied? If we are correct that state rules governing the selection of electors are, for federal constitutional purposes, considered the product of ordinary state legislative processes, that would seem to be a matter for each State to decide for itself. (We also suspect that even if state elector rules are a special species of state legislative action, it would still be up to each State to make this determination.) If, for instance, the Pennsylvania legislature had appended to its election laws a proviso that said, "In construing these statutes, give paramount weight to making it as easy as possible for the maximum number of people to cast ballots when there are health risks from appearing in person, even if that means that a number of "fraudulent' ballots get counted," is there any imaginable constitutional problem with that? We can't see it. And if that is implicitly the best account of the "Manner" by which the Pennsylvania legislature meant for electors to be chosen, then the state executive and judicial officials may have gotten it "right." Indeed, it is possible that implicit in the Pennsylvania statutory scheme is a proviso saying that whatever certain executive officials think is a good idea trumps statutory language. That may be an unwise scheme of statutory interpretation, but we cannot see how it could be unconstitutional.

A failure to appreciate that state legislatures determine all aspects of the "Manner" in which electors are chosen, including the interpretative principles necessary to ascertain that "Manner," was evident in 2000-01 in Bush v. Gore. ${ }^{71}$ For the young "uns who are not old enough to remember these events: The 2000 presidential election between George W. Bush and Al Gore came down to a few hundred ballots in Florida whose legality - and, in some cases, content where it was unclear whether a vote had been cast at all and for whom - was hotly disputed. The Florida Supreme Court, by a sharply divided vote, construed several sections of its State's election code involving such matters as deadlines for certifications, review of the decisions of canvassing boards, and the definition of "legal votes" under Florida law in a fashion that seemed to favor the electoral prospects of Gore, including by ordering a manual count of certain alleged votes in some but not all Florida counties. ${ }^{72}$ A seven-Justice majority of the U.S. Supreme Court found that the lack of uniform standards prescribed for these manual counts violated the Fourteenth

71 Bush v. Gore, 531 U.S. 98 (2000).

72 See Gore v. Harris, 772 So. 2 d 1243 (Fla. 2000) 
Amendment's Equal Protection Clause because it could lead to ballots from different voters in the State being assessed under different standards. ${ }^{73}$ (The Court divided 5-4 over the remedy for this claimed constitutional violation. ${ }^{74}$ )

While we both doubt whether the Fourteenth Amendment's Equal Protection Clause is a plausible source of principles governing the counting of state votes, ${ }^{75}$ the real action for the purposes of this essay came in a threeJustice concurrence authored by Chief Justice Rehnquist. The concurrence said that an additional ground for reversing the Florida Supreme Court, in addition to the equal protection problem, was that the Florida court's interpretation of the relevant state statutes "departs from the provisions enacted by the Florida Legislature,",76 "plainly departed from the legislative scheme," 77 and was even "absurd." " While federal courts normally defer entirely to interpretations of state law by the State's highest court, ${ }^{79}$ the Bush $v$. Gore concurrence maintained that Article II, section 1 makes state-law determinations in the selection of presidential electors a uniquely federal issue on which the federal courts are free to second-guess state court determinations. ${ }^{80}$ Even if that is so, and federal courts must make a de novo interpretation of the relevant state election laws when dealing with disputes about presidential elections, the concurrence took for granted that state statutes mean what their plain meaning prescribes. If that is true, then the concurrence had a real point: at least some of the interpretations advanced by

73 See 531 U.S. at 109.

74 See id. at 111, 144 (Breyer, J., dissenting).

75 To be fair to the Court in Bush v. Gore: The idea that equal protection principles govern state voting comes from the so-called "reapportionment cases," most notably Baker v. Carr, 369 U.S. 186 (1962), Wesberry v. Sanders, 376 U.S. 1 (1964), and Reynolds v. Sims, 377 U.S. 533 (1964), and has been a fixture of American constitutional law for more than half a century. While any or all of these cases might have been correctly decided under either the Guarantee Clause or general fiduciary principles, the Equal Protection Clause is, at first glance, an unlikely doctrinal hook.

76531 U.S. at 118 (Rehnquist, C.J., concurring).

77 Id.

$78 \mathrm{Id}$. at 119.

79 The origins of this doctrine are actually quite peculiar, but that is also a story for another time. See Gary Lawson \& Guy I. Seidman, Deference: The Legal ConcePt and the LeGal PRactice $55-58$ (2017).

80 See 531 U.S. at 112-13 (Rehnquist, C.J., concurring). We note that three current members of the Supreme Court may have recently endorsed a federal requirement that state courts, and presumably all state officials, adhere to a plain meaning interpretation and application of state statutory requirements for selecting presidential electors. See Republican Party of Pennsylvania v. DeGraffenreid, 141 S. Ct. 732 (2021); id. (Thomas J, dissenting from the denial of certiorari, slip op. at 4-5); id. (Alito, J. joined by Gorsuch, J., dissenting from the denial of certiorari, slip op. at 1-2). The Pennsylvania case contains the additional wrinkle that the state supreme court endorsed the departure from plain statutory language with reference to a constitutional requirement that elections be "free and equal," raising the possibility that federal court rejection of a state supreme court's ruling might compel state officials to violate their own state's constitution in order to comply with federal law. Id. at 1 (citing Pennsylvania Democratic Party v. Boockvar, 238 A.3d 345, 369-72 (Pa. 2020) and PA.ConST. Art. I, § 5). 
the Florida courts were, if not "absurd," then at least strained from the standpoint of plain-meaning textualist interpretation. But was that the right way to read Florida's election laws? Maybe. We don't know. Neither, we suspect, did the concurring Justices, since there was nothing in the opinion exploring in detail the norms of interpretation governing in Florida, either in 2000 or (perhaps more to the point?) when the various election statutes were enacted. That ascertainment of the correct interpretative norms is a necessary first step for determining the "Manner" by which a state legislature has fixed the process for choosing its State's electors.

To return to 2020: Did the Pennsylvania legislature direct, explicitly or implicitly, that its instructions for choosing presidential electors be understood in any "Manner" that would not give decisive weight to the plain meaning of statutory enactments? We do not know. This is a quickie essay, not a detailed research piece. Nor have we looked carefully at the methods, traditions, and understandings that might determine the meaning of instructions given by legislatures in Georgia, Michigan, Wisconsin, or other States. Quite possibly, one could get very different answers in each of those States.

Our best guess is that Vice President Pence did not know the answers to any of these state-law questions on January 6, 2021 either. (Neither, we strongly suspect, do the army of academics proclaiming Texas's challenges to the voting practices in those States to be "baseless" or "conspiracy theories." Maybe those challenges are both of those things, but such a determination would require a careful legal analysis for which few academics probably have the expertise or stomach.) Did he need to have those answers?

One possible path to "no" is simply to observe that if there is no controversy coming from a particular State's legislature about the validity of that State's certification, there is probably nothing for the Vice President, or the federal courts, to decide. If the State's legislature is happy with the certification, perhaps evidenced only by silence regarding the validity of the certificate provided by the electors, why isn't that conclusive proof that the electors were selected in the manner directed by that body? In that sense, the Supreme Court was correct to dismiss Texas's attempt to challenge the voting practices in other States - not because of Article III standing (which we both acknowledge might be an entirely bogus doctrine, though that is a topic for another day) but because, on the merits, the state legislatures appear to have spoken.

A more difficult question would be posed if members of a state legislature object that the State's purported certification of electoral votes is not the product of electors chosen in the manner directed by the legislature. In that circumstance, the Vice President probably does have to determine whether the document before him or her really is a "certificate" representing 
the votes of "Electors" chosen in the proper manner. That is unlikely to be something that can be determined in half an hour-or seven hours, or even several days. That is a very difficult, involved, complex matter of both fact and law. The Vice President is not necessarily going to be the best person to engage in that inquiry. But that is the person to whom the Constitution seems to commit the matter in the first instance.

All of which just serves as a reminder that the Constitution is what it is: A patchwork of provisions put together, across time, by eminently fallible humans. One does not expect congressional statutes to be exemplars of human wisdom and consistency. It is not obvious why one would expect more from the Constitution. See the Twelfth Amendment. 